\title{
Physico-Chemical Characteristics of Giant Featherback (Chitala lopis) and Mackerel (Scomberomorus commerson) Bone Gelatins and Their Potential as Gelling agents in Gel Mixtures for Roselle (Hibiscus sabdariffa L.) Soft Jelly Candies
}

\author{
Yuliani", Bambang Tri AGUNG, Marwati and Krishna Purnawan CANDRA \\ Department of Agricultural Technology Product, Agricultural Faculty of Mulawarman University, \\ Tanah Grogot, Kampus Gunung Kelua, Samarinda 75119, Indonesia
}

('Corresponding author's e-mail: yuliani@faperta.unmul.ac.id)

Received: 25 October 2017, Revised: 21 October 2018, Accepted: 9 November 2018

\begin{abstract}
The gel strength of gelatin depends on its raw material. Fish gelatin shows a broad range of gel strengths. Giant featherback and mackerel bone gelatins have the gel strengths 220 and 38 Bloom, respectively. Here, we prepared roselle soft jelly candy using the single gelatin and mixtures gelatins from bovine, giant featherback, and mackerel sources. Roselle calyces extract has been used as a food additive to improve taste, aroma, and antioxidant content. The soft jelly candies $(1.5 \% \mathrm{w} / \mathrm{v}$ roselle extract and 12 $\%$ gelling agent) were prepared using three types of gelatin (giant featherback (GF), mackerel (M), and bovine $(\mathrm{B})$ ) in four mixtures $(\mathrm{GF}: \mathrm{B}=1: 3, \mathrm{GF}: \mathrm{B}=1: 1, \mathrm{M}: \mathrm{B}=1: 3$, and $\mathrm{M}: \mathrm{B}=1: 1)$. This experiment was arranged in a completely randomized design with three replications for each treatment. Physico-chemical and sensory characteristics of the jelly candies were determined. The data were analyzed by ANOVA continued by the LSD test. The results showed that water content, $\mathrm{pH}$, gel strength, hardness, rigidity, and hedonic quality (taste, color, texture, and overall performance) of the roselle soft jelly candies were affected by choice of gelatin, but not total reducing sugar. Roselle soft jelly candy made with giant featherback and bovine gelatin $(1: 3)$ mix was the most preferred by the panelists.
\end{abstract}

Keywords: Gel strength, Roselle extract, Antioxidant, Soft jelly candy, amplang

\section{Introduction}

Gelatin is a common protein used in food products as a gelling agent. It is mainly derived from bovine and porcine bones that give the gel strengths 216 and 295 Bloom, respectively [1]. These are suitable for use in soft jelly candy, which contains 6 - $9 \%$ gelatin with gel strength 150 - 250 Bloom [2]. However, in the case of halal food, it is imperative to develop new potential gelatin sources. Fishbones are a potential halal acceptable source of gelatin. Amplang, an iconic fish cracker in Samarinda, Indonesia, uses giant featherback and mackerel as the raw materials. However, the bones are not yet optimally utilized in food and feed uses.

Gel strength from fish gelatin depends on the type of fish and choice of tissue used as raw material. Recently, we reported the gel strengths of gelatins from the skin and bone of mackerel as 30 and 84 Bloom, respectively [3]. However, there are fish gelatins with 3 - 5 fold higher gel strengths. Pranoto et al. [4] reported that skin gelatin from yellowfin tuna, brown stingray, red snapper, and white cheek shark (captured in Indonesia) have the gel strengths 159, 266, 219 and 227 Bloom, respectively. Cho et al. [1] reported an even higher gel strength for skin gelatin (429 Bloom) from yellowfin tuna provided by Korean fisheries. The broad range of fish gelatin gel strengths is a challenge when constructing a gelatin mix suitable for a specific product. 
http://wjst.wu.ac.th

Roselle calyces are popular as acidic tea and rich in vitamin $\mathrm{C}$, malic acid, and citric acid, as well as minerals like calcium, phosphor, iron, and sodium [5,6]. Extract of roselle calyces is now also used in beverages with a strong taste, acidity, and abundant antioxidants [7,8]. It has a high potential for use in preparing soft jelly candy [9,10] with high antioxidant content, acting as functional food [11-19]. The acidity of roselle calyces extracts potentially reduces the gel strength of gelatin, which is used as the gelling agent in roselle soft jelly candy. Rahmi et al. [20] reported on roselle calyces extract jelly candies. However, the gelatin concentration used in the process was triple that in common jelly candies $(6-9 \%)$ $[2]$.

Carbohydrate-gelatin mixtures might be an alternative for achieving suitable gel strength and gel hardness with a gelling agent at a low concentration, however, with loss of chewiness/springiness, clarity/turbidity, and overall sensory acceptance [21-23]. Karim and Bhat [24] reported that fish gelatin is an alternative to mammalian gelatin, and here we report on mixtures of fish (giant featherback and mackerel) and bovine gelatins to prepare roselle soft jelly candy.

\section{Materials and methods}

\section{Materials}

Gelatins were prepared from giant featherback, mackerel, and bovine bones. Giant featherback and mackerel bones were obtained from amplang small industry waste in Samarinda, while bovine bones were obtained from a commercial market in Samarinda. Amplang is a local special fish cracker made of giant featherback or mackerel in East Kalimantan. Roselle extract was prepared from roselle calyces obtained from farmers around Samarinda. HFS (55\% fructose, $38 \%$ glucose, and $7 \%$ oligosaccharide), sucrose, guar gum, potassium sorbic, and strawberry essence were obtained from a local bakery in Samarinda. Chemicals used in this experiment were analytical grade obtained from Merck and Roedelheim.

Table 1 Gel alternatives in roselle jelly candies production $(12 \%, \mathrm{w} / \mathrm{v})$.

\begin{tabular}{lccc}
\hline \multicolumn{1}{c}{ Type of gel } & \multicolumn{3}{c}{ Gelatin (g) } \\
\cline { 2 - 4 } & GF & M & B \\
\hline Giant featherback bone gelatin (GF) & 6.0 & - & - \\
Mackerel bone gelatin (M) & - & 6.0 & 6.0 \\
Bovine bone gelatin (B) & - & - & 4.5 \\
GF25 (GF:B $=1: 3)$ & 1.5 & - & 3.0 \\
GF50 (GF:B $=1: 1)$ & 3.0 & - & 4.5 \\
MG25 (M:B $=1: 3)$ & - & 1.5 & 3.0 \\
MG50 (M:B $=1: 1)$ & - & 3.0 & \\
\hline
\end{tabular}

Note: The roselle jelly candies were prepared with $6 \mathrm{~g}$ gelatin in $50 \mathrm{~mL}$ of hot water roselle calyces extract, and addition of sugar, HFS, guar gum, potassium sorbic, and strawberry essence at the amounts $17.5,2.5,1.5,0.05 \mathrm{~g}$, and five drops, respectively. 


\section{Experimental design and data analysis}

A single factor (type of gel/gel system) experiment arranged in a completely randomized design was applied in this research. The factor levels were the 7 treatments or alternatives, namely giant featherback bone gelatin (GF), mackerel bone gelatin (M), bovine bone gelatin (B), GF25 (GF:B = 1:3), GF50 (GF:B $=1: 1), \operatorname{M} 25(\mathrm{M}: \mathrm{B}=1: 3)$, and M50 $(\mathrm{M}: \mathrm{B}=1: 1)$ (Table 1). Each treatment was repeated three times. The roselle jelly candy was assessed for physical characteristics (gel strength, gel hardness, and gel rigidity), chemical characteristics ( $\mathrm{pH}$, total acid, and total reducing sugar), and sensory characteristics (preference, taste, color, and texture).

Data were analyzed using ANOVA combined with LSD follow-up test for significant differences. Sensory data were transformed to interval data by the Method of Successive Intervals, before analysis by ANOVA.

\section{Experimental procedure \\ Gelatin preparation}

Gelatins from the three sources (giant featherback, mackerel, and bovine bones) were prepared, as described in [3]. The bones were washed to remove scales, meat, and fat under running water, followed by degreasing in boiling water for $30 \mathrm{~min}$ for giant featherback and mackerel bones, and for $3 \mathrm{~h}$ for the bovine bones, then cutting the bones to 2 - $3 \mathrm{~cm}$ length. The cut bones were then soaked in $4 \% \mathrm{HCl}$ to demineralize, for 24, 48, and $72 \mathrm{~h}$ for lopis mackerel, giant featherback, and bovine bones, respectively. $\mathrm{The} \mathrm{HCl}$ was then removed, and ossein (demineralized bones) were neutralized in $0.01 \mathrm{~N} \mathrm{NaOH}$ followed by washing with aquadest. Ossein was then extracted for gelatin in hot water $(1: 3 \mathrm{w} / \mathrm{w})$ at $80{ }^{\circ} \mathrm{C}$ for $6 \mathrm{~h}$ in a glass beaker. The thick filtrate from the gelatin extraction was cooled at $4{ }^{\circ} \mathrm{C}$ for $12 \mathrm{~h}$, followed by drying in an oven at $50{ }^{\circ} \mathrm{C}$ for $48 \mathrm{~h}$ to form solid gelatin. Then, the gelatin was powdered, its yield was determined, and its characteristics (moisture content, $\mathrm{pH}$, and gel strength) were measured.

\section{Roselle extract preparation}

Deep red and fresh roselle calyces from roselle plants at about four months of age were used in this experiment. Roselle extract preparation was modified from [20]. Dried roselle calyces were prepared in an oven at $70{ }^{\circ} \mathrm{C}$ for $7 \mathrm{~h}$ before extraction. Roselle seeds inside the calyces were removed before drying. Dried roselle calyces $(6 \mathrm{~g})$ were soaked in $400 \mathrm{~mL}$ boiling water $(1.5 \% \mathrm{w} / \mathrm{v})$ for $15 \mathrm{~min}$, and the filtrate through a filter paper was used to prepare roselle jelly candy.

\section{Roselle jelly candy preparation}

Roselle jelly candies were prepared by pouring $6 \mathrm{~g}$ of gelatin (mix) gently in $50 \mathrm{~mL}(12 \% \mathrm{w} / \mathrm{v})$ of roselle calyces extract at $90{ }^{\circ} \mathrm{C}$, mixing for $1 \mathrm{~min}$ (until all gelatin was dissolved), and guar gum was added while stirring, then adding sugar, HFS, potassium sorbic, and strawberry essence at the amounts $17.5,2.5,1.5,0.05 \mathrm{~g}$, and 5 drops, respectively. The mixing was continued at $100{ }^{\circ} \mathrm{C}$ for 2 min while adding potassium sorbic and strawberry essence. The strawberry essence was aimed to cover up the gelatin aroma. The mixture was then put in candy molds, covered, and left at room temperature for $1 \mathrm{~h}$. The roselle jelly candies were then stored at $4{ }^{\circ} \mathrm{C}$ for $24 \mathrm{~h}$ to give them good solid form.

Assays

Acidity was assayed using a pH-meter and titrimetry with malic acid [25], while total reducing sugar was assayed by Luff Schoorl method SNI 3547-2-2008 [26]. Moisture and protein content was determined by the oven method and micro Kjeldahl method, respectively [27]. The strength, hardness, and rigidity of roselle jelly candies were determined using Stevens-LFRA Texture Analyzer [2]. Sensory characteristics were determined by 20 semi-trained panelists [28]. 
http://wjst.wu.ac.th

\section{Results and discussion}

Yield and characteristics of gelatins from giant featherback, mackerel and bovine bones

Gelatin extraction from fish and bovine bones by hot water, following a pre-treatment by soaking in $4 \% \mathrm{HCl}$ for $48 \mathrm{~h}$ (giant featherback), $24 \mathrm{~h}$ (mackerel), or $72 \mathrm{~h}$ (bovine), gave the yields 7.88, 6.65, and $8.02 \%$ for giant featherback, mackerel, and bovine bones, respectively. The characteristics of the three gelatins are shown in Table 2.

Table 2 Characteristics of gelatins from giant featherback, mackerel, and bovine bones.

\begin{tabular}{lccc}
\hline Gelatin source (bones) & Moisture content $(\%)$ & pH* & Gel strength $\left(\mathbf{G f} / \mathbf{c m}^{\mathbf{2}}\right)$ \\
\hline Giant featherback & $(9.33 \pm 0.25) \mathrm{a}$ & $(4.22 \pm 0.03) \mathrm{b}$ & $(219.98 \pm 5.58) \mathrm{a}$ \\
Mackerel & $(6.78 \pm 0.18) \mathrm{c}$ & $(2.87 \pm 0.03) \mathrm{c}$ & $(38.43 \pm 1.52) \mathrm{c}$ \\
Bovine & $(8.02 \pm 0.37) \mathrm{b}$ & $(4.84 \pm 0.03) \mathrm{a}$ & $(175.54 \pm 6.09) \mathrm{b}$ \\
\hline
\end{tabular}

Note: Data (average \pm std error) were calculated from 3 replications. The data were analyzed by ANOVA. Values in the same column, followed by different letters, are significantly different (LSD test, $p<0.05$ ). *) $\mathrm{pH}$ was determined using $1 \%$ gelatin at room temperature.

At the standard of $6.67 \%$ gelatin concentration, mackerel gelatin turned into liquid form within 10 min at room temperature, following gel-forming at $4{ }^{\circ} \mathrm{C}$. At the same time, the other two gelatins stayed in gel form at room temperature.

Physico-chemical characteristics of roselle jelly candies

The choice of gel affected all physical parameters observed (gel strength, gel hardness, and gel rigidity) for the roselle jelly candies (Table 3). It also significantly affected the chemical parameters observed, namely moisture content, $\mathrm{pH}$, and total titrated acid, but not the reduction of sugar content (Table 4).

Table 3 Influence of gel type on gel strength, hardness, and rigidity in roselle jelly candies.

\begin{tabular}{|c|c|c|c|}
\hline Type of gel & Gel strength $\left(\mathbf{G f} / \mathrm{cm}^{2}\right)$ & Gel hardness (Gf) & Gel rigidity $(\mathrm{Gf} / \mathrm{cm})$ \\
\hline Giant featherback gelatin (GF) & $(1,976.62 \pm 48.75) \mathrm{c}$ & $(380.10 \pm 9.38) \mathrm{c}$ & $(1,465.60 \pm 6.81) \mathrm{c}$ \\
\hline Mackerel gelatin (M) & $\mathrm{nd}^{*}$ & $\mathrm{nd}^{*}$ & nd* \\
\hline Bovine gelatin (B) & $(1,630 \pm 18.05) \mathrm{d}$ & $(313.59 \pm 3.47) \mathrm{d}$ & $(1,133.25 \pm 9.18) \mathrm{c}$ \\
\hline GF25 (GF:B = 1:3) & $(2,521.04 \pm 16.47) b$ & $(484.80 \pm 3.17) b$ & $(1,291.78 \pm 12.07) b$ \\
\hline GF50 (GF:B = 1:1) & $(4,660.95 \pm 17.47) \mathrm{a}$ & $(896.30 \pm 3.36) a$ & $(2,962.32 \pm 6.48) \mathrm{a}$ \\
\hline M25 (M:B = 1:3) & $(1,244.92 \pm 9.50) \mathrm{e}$ & $(239.40 \pm 1.82) \mathrm{e}$ & $(1,017.42 \pm 1.38) \mathrm{c}$ \\
\hline M50 (M:B = 1:1) & $(625.69 \pm 4.94) \mathrm{f}$ & $(120.51 \pm 0.95) \mathrm{f}$ & $(617.62 \pm 6.24) d$ \\
\hline Commercial jelly candy & $(5,549.52 \pm 12.21)$ & $(1,067.17 \pm 2.35)$ & $(5,442.50 \pm 24.99)$ \\
\hline
\end{tabular}


http://wjst.wu.ac.th

Table 4 Influence of gel-type on chemical characteristics of roselle jelly candies.

\begin{tabular}{lcrrr}
\hline Type of gel & $\begin{array}{c}\text { Moisture content } \\
(\mathbf{\%})\end{array}$ & \multicolumn{1}{c}{$\mathbf{p H}^{*}$} & $\begin{array}{c}\text { Total of titrated acid } \\
\text { (as \% malic acid) }\end{array}$ & $\begin{array}{c}\text { Reducing } \\
\text { sugar (\%) }\end{array}$ \\
\hline Giant featherback gelatin (GF) & $(19.38 \pm 0.15) \mathrm{b}$ & $(3.47 \pm 0.03) \mathrm{cd}$ & $(1.51 \pm 0.23) \mathrm{bc}$ & $(8.40 \pm 0.70)$ \\
Mackerel gelatin (M) & $(24.22 \pm 0.74) \mathrm{a}$ & $(2.43 \pm 0.20) \mathrm{e}$ & $(2.94 \pm 0.48) \mathrm{a}$ & $(9.17 \pm 0.30)$ \\
Bovine gelatin (B) & $(17.76 \pm 0.39) \mathrm{c}$ & $(4.30 \pm 0.06) \mathrm{a}$ & $(0.95 \pm 0.11) \mathrm{c}$ & $(8.56 \pm 1.31)$ \\
GF25 (GF:B =1:3) & $(12.89 \pm 0.18) \mathrm{e}$ & $(4.30 \pm 0.25) \mathrm{a}$ & $(1.29 \pm 0.19) \mathrm{bc}$ & $(7.88 \pm 0.24)$ \\
GF50 (GF:B = 1:1) & $(13.66 \pm 0.46) \mathrm{e}$ & $(3.93 \pm 0.03) \mathrm{ab}$ & $(1.40 \pm 0.24) \mathrm{bc}$ & $(8.83 \pm 0.44)$ \\
M25 (M:B = 1:3) & $(15.82 \pm 0.31) \mathrm{d}$ & $(3.73 \pm 0.12) \mathrm{bc}$ & $(1.52 \pm 0.15) \mathrm{bc}$ & $(7.25 \pm 1.40)$ \\
M50 (M:B = 1:1) & $(16.68 \pm 0.55) \mathrm{cd}$ & $(3.10 \pm 0.15) \mathrm{d}$ & $(1.99 \pm 0.23) \mathrm{b}$ & $(8.56 \pm 0.44)$ \\
\hline
\end{tabular}

Note: Data (average \pm std error) are from 3 replications. The data were analyzed by ANOVA. Values in the same column, followed by different letters, are significantly different (LSD test, $p<0.05$ ). *) Determined before the candies became solid following the cooling step in roselle jelly candy production.

The type of gelatin (mix) affected the $\mathrm{pH}$ of roselle jelly candies. The mixed gelatin affected the moisture content in the roselle jelly candies because acidity (low $\mathrm{pH}$ of the roselle calyces extract) can cause partial hydrolysis of the gelatin. Mahadevan et al. [5] reported that malic acid and citric acid were found in roselle calyces, which cause the roselle jelly candies to absorb more water. Mackerel gelatin at a concentration of $12 \%$ cannot be used alone for roselle jelly candies, because this gelatin gave a thick liquid even at $4{ }^{\circ} \mathrm{C}$. The moisture content of roselle jelly candies from mackerel gelatin was $24.22 \%$, which is higher than the moisture content of jelly candies allowed by national standards of Indonesia (maximally $20 \%$ ) [26].

Roselle jelly candies produced by using lopis or bovine gelatin alone had the moisture contents 19.38 and $17.76 \%$, respectively. Both these gelatins were soft-solid gels at room temperature. The substitution of bovine gelatin with fish gelatin increased the moisture content of the gel mix. The mixed gel appeared more resistant to partial acid hydrolysis by the roselle calyces extract, forming solid and chewy roselle jelly candies. Roselle jelly candies produced with a mixture of bovine and lopis gelatin at a 3:1 ratio (LG25) had better physical properties than the 1:1 case (LG50) (Table 3). Roselle jelly candies produced with mixtures of bovine and mackerel gelatins in the case 1:1 (MG50) were solid soft jelly, while the case 3:1 (MG25) gave better physical properties in the roselle jelly candies. On the other hand, roselle jelly candy produced with $12 \%$ mackerel gelatin alone was not solid.

Rahmi et al. [20] reported that gel strength of roselle jelly candy at $12 \%$ gelatin from bovine bone was 178.1 Gf, but did not give any information about the gel strength of a reference product like commercial jelly candies. In this current study, we showed that $12 \%$ gelatin of bovine bones has gel strength 3.4 times lower than the commercial one, and gel hardness three times lower (Table 3).

\section{Hedonic sensory characteristic of roselle jelly candies}

The type of gel system affected all the sensory characteristics observed (Table 5). The mixed gel from bovine and lopis gelatin in the 3:1 case (LG25) and 1:1 case (LG50), or a mix of bovine and mackerel in the 3:1 case (MG25), gave good responses from the panelists. The panelists liked the roselle jelly candies made from bovine gelatin. 
http://wjst.wu.ac.th

Table 5 Influences of gel-type on sensory characteristics of roselle jelly candy.

\begin{tabular}{|c|c|c|c|c|}
\hline \multirow[b]{2}{*}{ Type of gel } & \multirow{2}{*}{$\begin{array}{c}\text { Hedonic quality } \\
\text { Overall } \\
\text { preferences } \\
\end{array}$} & \multicolumn{3}{|c|}{ Hedonic } \\
\hline & & Taste & Color & Texture \\
\hline Giant featherback gelatin (GF) & $(3.89 \pm 0.15) \mathrm{e}$ & $(4.36 \pm 0.09) \mathrm{b}$ & $(2.78 \pm 0.14) \mathrm{c}$ & $(2.35 \pm 0.14) \mathrm{d}$ \\
\hline Mackerel gelatin (M) & $(3.41 \pm 0.05) \mathrm{d}$ & $(5.07 \pm 0.18) \mathrm{a}$ & $(1.91 \pm 0.08) \mathrm{d}$ & $(1.54 \pm 0.14) \mathrm{e}$ \\
\hline Bovine gelatin (B) & $(4.41 \pm 0.10) \mathrm{ab}$ & $(3.82 \pm 0.11) \mathrm{c}$ & $(3.46 \pm 0.04) \mathrm{ab}$ & $(3.18 \pm 0.07) b c$ \\
\hline GF25 (GF:B = 1:3) & $(4.71 \pm 0.18) \mathrm{a}$ & $(3.80 \pm 0.07) \mathrm{c}$ & $(3.59 \pm 0.03) \mathrm{a}$ & $(3.72 \pm 0.14) \mathrm{a}$ \\
\hline GF50 (GF:B = 1:1) & $(4.41 \pm 0.06) a b$ & $(3.66 \pm 0.04) \mathrm{c}$ & $(3.60 \pm 0.07) \mathrm{a}$ & $(3.31 \pm 0.08) b$ \\
\hline M25 (M:B = 1:3) & $(4.16 \pm 0.02) b c$ & $(3.90 \pm 0.09) \mathrm{c}$ & $(3.37 \pm 0.05) \mathrm{ab}$ & $(3.21 \pm 0.13) b c$ \\
\hline M50 (M:B = 1:1) & $(3.87 \pm 0.12) \mathrm{c}$ & $(4.23 \pm 0.02) b$ & $(3.22 \pm 0.16) b$ & $(2.96 \pm 0.04) \mathrm{c}$ \\
\hline
\end{tabular}

Note: Data (average \pm std error) were average from 60 values. Data were transformed into intervals by the Method of Successive Intervals (MSI) before analysis by ANOVA. Values in the same column, followed by different letters, were significantly different (LSD test, $p<0.05$ ). Scale for sensory characteristics following data transformation by MSI:

- Hedonic for overall preference: 1.00 - 2.11 (rather dislike), 2.12 - 3.91 (rather like), 3.92 - 5.27 (like), 5.28 - 5.93 (like very much).

- Hedonic quality for taste: 1.00 - 1.98 (very sweet), 1.99 - 3.62 (sweet), 3.63 - 4.88 (sour-sweet), 4.89 - 6.07 (sour), 6.08 - 6.66 (very sour).

- Hedonic quality scale for color: 1.00 - 1.43 (light red), $1.44-2.27$ (red), 2.28 - 3.12 (rather purple-red), 3.13 - 4.11 (purple-red), 4.12 - 4.66 (purple).

- Hedonic quality scale for texture: 1.00 - 1.42 (liquid), 1.43 - 2.25 (thick), 2.26 - 3.17 (solid rather chewy), 3.18 - 4.37 (solid and chewy), 4.38 - 5.04 (solid and very chewy).

Mackerel gelatin alone at $12 \%$ gave a sour taste to the roselle jelly candies, while bovine gelatin or mix or bovine and lopis gelatins gave a sour-sweet taste. The sour taste of roselle jelly candies from mackerel gelatin might come from partial hydrolysis, due to its high content of amino acid. Acidity was essential to the performance of roselle jelly candies. It affected the physical characteristics as well as color and texture. The color of roselle jelly candies was red to purple-red. This range of color might have been caused by the color of anthocyanins being affected by $\mathrm{pH}$. Roselle calyces are abundant in anthocyanins [29], which give red, purple, and blue colors to plants [30]. Anthocyanin gave an intense red color at $\mathrm{pH}<3.5$, and the color intensity was reduced at $\mathrm{pH}>4.5$ [31].

\section{Conclusions}

Mixing fish and bovine bone gelatins affected the chemical, physical, and sensory characteristics of roselle jelly candies. Mackerel gelatin at $12 \%$ was not suitable for roselle jelly candies. The substitution of bovine gelatin with lopis gelatin improved the physical characteristics of roselle jelly candies and was preferred by the panelists. Mixed bovine and lopis gelatin at ratio 3:1 were the most preferred by the panelists. 
http://wjst.wu.ac.th

\section{Acknowledgements}

The authors thank the Ministry of Research, Technology, and Higher Education of the Republic of Indonesia for financial support (Competitive Grant / Hibah Bersaing 2015).

\section{References}

[1] SM Cho, YS Gu and SB Kim. Extracting optimization and physical properties of yellowfin tuna (Thunnus albacares) skin gelatin compared to mammalian gelatins. Food Hydrocoll. 2005; 19, 2219.

[2] J Poppe. Gelatin. In: AP Imeson (Ed.). Thickening and Gelling Agents for Food. $2^{\text {nd }}$ ed. Aspen Publishers, Gaithersburg, Maryland, 1999, p. 144-68.

[3] Yuliani and Marwati. Extraction and characterization of fish Mackerel (Scomberomorus commerson) gelatin (in Indonesian). J. Teknol. Pertan. Univ. Mulawarman 2015; 10, 1-7.

[4] Y Pranoto, DW Marseno and H Rahmawati. Characteristics of gelatins extracted from fresh and sun-dried seawater fish skins in Indonesia. Int. Food Res. J. 2011; 18, 1335-41.

[5] N Mahadevan, S Kamboj and P Kamboj. Hibiscus sabdariffa Linn.: An overview. Nat. Prod. Radiance 2009; 8, 77-83.

[6] SB Fasoyiro, SO Babalola and T Owosibo. Chemical composition and sensory quality of fruitflavoured roselle (Hibiscus sabdariffa) drinks. World J. Agric. Sci. 2005; 1, 161-4.

[7] P-J Tsai, J McIntosh, P Pearce, B Camden and BR Jordan. Anthocyanin and antioxidant capacity in roselle (Hibiscus sabdariffa L.) extract. Food Res. Int. 2002; 35, 351-6.

[8] AA Abou-Arab, FM Abu-Salem and EA Abou-Arab. Physico-chemical properties of natural pigments (anthocyanin) extracted from Roselle calyces (Hibiscus sabdariffa). J. Am. Sci. 2011; 7, 445-56.

[9] CE Tamer, B İncedayı, ÖU Çopur and M Karınca. A research on the fortification applications for jelly confectionery. J. Food Agric. Environ. 2013; 11, 152-7.

[10] A Muawanah, I Djajanegara, A Sa'duddin, D Sukandar and N Radiastuti. Penggunaan bunga kecombrang (Etlingera elatior) dalam proses formulasi permen jelly (in Indonesian). Valensi 2012; 2, 526-33.

[11] Zuraida, E Yerizel and E Anas. Effect of rosella (Hibiscus sabdariffa Linn.) extract addition on malondialdehid content and catalase activity of rat exposed to tetrachloride (in Indonesian). J. Kesehat. Andalas 2015; 4, 795-802.

[12] NJ Ritonga, O Setiani, Umaroh, K Budhi and F Amri. Roselle flower (Hibiscus sabdariffa) in the treatment of hypertension in postpartum mothers. Belitung Nurs. J. 2017; 3, 229-37.

[13] Mozaffari-Khosravi, BA Hassan, Jalali-Khanabadi, Afkhami-Ardekani, Mohammad and F Fatehi. Effects of sour tea (Hibiscus sabdariffa) on lipid profile and lipoproteins in patients with type II diabetes. J. Altern. Complement. Med. 2009; 15, 899-903.

[14] Nurkhasanah and LR Zulkarmen. The effect of roselle (Hibiscus sabdariffa L.) calyx ethanolic axtract on the secrestion of nitrit oxide (NO) of peritoneal macrophage of 7,12dimethylbenz $(\alpha)$ antracene (DMBA) induced rats (in Indonesian). Media Farm. 2014; 11, 155-66.

[15] AM Salah, J Gathumbi and W Vierling. Inhibition of intestinal motility by methanol extracts of Hibiscus sabdariffa L. (Malvaceae) in rats. Phyther. Res. 2002; 16, 283-5.

[16] JY Liu, CC Chen, WH Wang, JD Hsu, MY Yang and CJ Wang. The protective effects of Hibiscus sabdariffa extract on CCl4-induced liver fibrosis in rats. Food Chem. Toxicol. 2006; 44, 336-43.

[17] L Indriani and M Dharmautama. Antimicrobial test of roselle (Hibiscus sabdariffa L.) ethanol extract against Porphyromonas gingivalis and Streptococcus sanguis using agar method (in vitro study). J. Dentomaxillofacial Sci. 2016; 1, 287-93.

[18] V Hirunpanich, A Utaipat, NP Morales, N Bunyapraphatsara, H Sato, A Herunsale and C Suthisisang. Hypocholesterolemic and antioxidant effects of aqueous extracts from the dried calyx of Hibiscus sabdariffa L. in hypercholesterolemic rats. J. Ethnopharmacol. 2006; 103, 252-60.

[19] E Wisetmuen, P Pannangpetch, B Kongyingyoes, U Kukongviriyapan, W Yutanawiboonchai and A 
http://wjst.wu.ac.th

Itharat. Insulin secretion enhancing activity of roselle calyx extract in normal and streptozotocininduced diabetic rats. Pharmacognosy Res. 2013; 5, 65-70.

[20] SL Rahmi, F Tafzi, and S Anggraini. Effect of gelatine addition on jelly candy from roselle (Hibiscus sabdariffa Linn) calyces (in Indonesian). J. Penelit. Univ. Jambi Seri Sains. 2012; 14, 3744.

[21] IJ Haug, KI Draget and O Smidsrød. Physical behaviour of fish gelatin- $\kappa-c a r r a g e e n a n$ mixtures. Carbohydr. Polym. 2004; 56, 11-9.

[22] N Somboon, TT Karrila, T Kaewmanee and SJ Karrila. Properties of gels from mixed agar and fish gelatin. Int. Food Res. J. 2014; 21, 485-92.

[23] Eveline, J Santoso and I Widjaja. Study on concentration and ratio of catfish skin gelatin and kappa carrageenan in jelly making (in Indonesian). J. Pengolah. Has. Perikan. Indones. 2011; 15, 98-105.

[24] AA Karim and R Bhat. Fish gelatin: Properties, challenges, and prospects as an alternative to mammalian gelatins. Food Hydrocoll. 2009; 23, 563-76.

[25] LG. Hargis. Analytical Chemistry: Principles and Techniques. Prentice Hall, New Jersey US, 1988, p. $1-424$.

[26] Badan Standardisasi Nasional. Indonesian National Standard 3547.2-2008 Cotton candy - $2^{\text {nd }}$ Part: Soft (in Indonesian). Badan Standardisasi Nasional, Jakarta, 2008, p. 1-42.

[27] S Sudarmadji, B Haryono and Suhardi. Analysis Procedure of Food and Agriculture Product (in Indonesian). Liberty, Yogyakarta, 2010, p. 1-60.

[28] D Setyaningsih, A Apriantono and MP Sari. Sensory Analysis of Food and Agroindustry (in Indonesian). Bogor: IPB Press, 2010, p. 1-180.

[29] HR Juliani, CR Welch, Q Wu, B Diouf, D Malainy and JE Simon. Chemistry and quality of hibiscus (Hibiscus sabdariffa) for developing the natural-product industry in Senegal. J. Food Sci. 2009; 74, S113-S121.

[30] A Castañeda-Ovando, MDL Pacheco-Hernández, ME Páez-Hernández, JA Rodríguez and CA Galán-Vidal. Chemical studies of anthocyanins: A review. Food Chem. 2009; 113, 859-71.

[31] RL Newsome. Natural and synthetic coloring agents. In: AL Branen, PM Davidson and S Salminen (Eds.). Food Additives. Marcel Dekker, New York, 1990, p. 327-45. 